\title{
4 \\ Learning to share emotions through ritual participation among the Toraja of Sulawesi
}

Roxana Waterson

\section{Introduction: The anthropology of the emotions and the concept of empathy}

Anthropology has always been about two big questions-simply expressed: what makes humans everywhere the same and what makes us different? Just like comparative studies of language and rationality, the anthropology of emotions has been an important testing ground for the exploration of these always interrelated questions. Austronesian ethnography has played a significant role in the development of anthropological thinking about the emotions (see, for example, Geertz 1974; Heider 1991; Levy 1973; Lutz 1988; Lutz and White 1986; M. Rosaldo 1980; R. Rosaldo 1984; White 1993; White and Kirkpatrick 1985, to mention only a few). In these works, there is a strong focus on indigenous discourse about emotions, their acceptable expression and the socially patterned intentions that shape them, while some outstanding studies, such as those by the Rosaldos on Ilongot liget or by Lutz on Ifaluk fago, have presented detailed analyses of culturally unique emotional concepts or complexes of ideas. 
Much less has been written to date about the comparative ethnography of an ethos of empathy or on the question of how children, as subjects actively involved in the reproduction of culture, learn what is expected of them in the realm of shared emotions. The idea of ethos was notably employed by Gregory Bateson (1958: 32-3) in his highly original study of Iatmul society to talk about 'the emotional emphases of [a] culture' (as distinct from eidos, which he defined as the standardised cognitive aspects involved in the premises of a particular culture). Ethnographers working both within and beyond the Austronesian world have noted that culturally salient ideas about emotions help to establish particular concepts of personhood and 'modes of relationship' (Levy 1973: 271), and ultimately the moral order itself. Children, it has been argued, absorb a particular cultural ethos, not only through what they hear adults say about emotions, but also, and perhaps more importantly, through direct experience of social interactions or participation in collective activities in which local theories of the emotions are implicitly embedded (Myers 1979). Toren's studies in Fiji $(1990,1999,2006)$ have made pathbreaking contributions in examining how children form their own ideas about how their culture works. The ideas of these authors provide a starting point for this chapter, which examines the emotional content of Toraja children's accounts of what they have learned from attendance at rituals.

Any discussion of the contributions made to the study of emotions by ethnographers of Austronesian societies would be incomplete without reference to the substantial body of work by Douglas Hollan and Jane Wellenkamp on the Toraja of Sulawesi (Hollan 1988, 1990, 1992a, 1992b, 2008, 2011; Hollan and Wellenkamp 1994, 1996; Wellenkamp 1984, 1988, 1991, 1992). Wellenkamp in particular has focused on emotions associated with death and grieving, which have a special importance for the Toraja given the salience they accord to funerary rituals as social occasions-I shall say more about this in a moment. Hollan and Wellenkamp's research was based largely on life-history interviews with adults. Since the study I am going to discuss was done with children, I hope to be able to extend their insights by seeing what can be learned from this still much neglected constituency of research participants. I should say at the outset that exploring empathy or emotional expression was not the original intention of the investigation. Seeking to discover what Toraja children think about the complex ceremonial system in which as adults they will be expected to participate, at great financial cost, it was quite by chance that I found many of the children had written about a felt 
need or duty to share in the feelings of others. I am encouraged to explore this further by the fact that Hollan, in collaboration with Jason Throop (Hollan and Throop 2008, 2011), has recently turned his attention to the cross-cultural study of empathy, a concept that is currently of consuming interest also to neuroscientists and evolutionary biologists. In what follows, I hope to pick up on some threads of their discussion, while adding a new perspective to the already extensive ethnography of ritual among the Toraja.

The discovery of mirror neurons has triggered intense and still vexed debate in the biological sciences about their possible role in providing a neurological basis for empathy and theory of mind-capabilities that, while not totally unique to humans, are clearly developed in our species to a quite remarkable degree. ${ }^{1}$ Not all social scientists, however, keep up with the rapid developments taking place in biology, or they may explicitly reject the possibility that these could have the slightest relevance to what we are doing. Hollan and Throop (2008), in their introduction to a special issue of Ethos on the problem of empathy in anthropology, note that 'empathy has remained muted in anthropological discussion to the extent that it is often oddly absent from even the most relevant of studies' (p. 386), although related issues to do with intentionality and theory of mind may possibly have been serving 'as a means to bring empathy back into anthropology through the back door' (p. 385). ${ }^{2}$ Anthropological aversion to a consideration of empathy, Hollan and Throop suggest, may be laid at the door of Clifford Geertz (1984), who famously dismissed the concept in his oft-cited essay 'From the native's point of view: On the nature of anthropological understanding'. But the content of that essay, in fact, has nothing to do with efforts to understand empathy from an evolutionary perspective or its role in enabling complex sociality in humans. Geertz was simply having a dig at Malinowski's own claims to special anthropological gifts of empathic understanding-claims that could be put in perspective following the posthumous publication of the latter's diaries. These revealed — to much declared shock in anthropological

1 To review these debates is beyond the scope of this chapter, but, on mirror neurons and empathy, see Bastiaansen et al. (2009); Decety and Ickes (2009); Decety and Jackson (2004); Gallese (2001, 2007); Iacoboni (2008); Iacoboni et al. (2005); Preston and de Waal (2002); Rizzolatti and Craighero (2004); Stamenov and Gallese (2002). For evolutionary and developmental perspectives on empathy, see Baron-Cohen (2011); Eisenberg and Strayer (1987); Frith (2007); Gallagher (2012); Hoffman (2000); Young (2012).

2 For a recent comparative contribution in this field, with a focus on Pacific societies, see Wassmann et al. (2013). 
quarters at the time- that he had not unfailingly enjoyed his fieldwork and, when having an off day, was not above recording embarrassing comments about his Trobriand acquaintances in the putatively private space of his personal journal. In their recent book The Anthropology of Empathy (2011: 2), which focuses on Pacific societies, Hollan and Throop note that empathy 'remains a woefully understudied and unanalysed form of behaviour' in anthropology. This did not stop a reviewer of the book from dismissing the concept as unworthy of serious anthropological investigation (Rollason 2012). Dwelling on the difficulties of definition, and the obvious limitations of using English as the language of discussion for issues of comparative ethnography, Rollason (2012: 707) concludes: 'Empathy, one feels reading this collection, is too flimsy a notion to accommodate the excellent ethnographic work that the individual essayists have produced.' This easy dismissal might be due to the reviewer not having considered any of the neurological literature painstakingly referenced by the authors or it might indicate the adoption of a certain postmodernist position of extreme cultural relativism, from which the according of any special precedence to the findings of natural scientists is discounted as yet another hegemonic manoeuvre. That attitude is regrettable, however, since, as Ingold (1985: 16) passionately argued long ago, it cuts us off from asking questions about what makes us human, and risks leaving 'a vacuum that the more bigoted practitioners of other disciplines are only too eager to fill'. ${ }^{3}$ What is more to the point now, in today's 'postgenomic' age, is that we should not inadvertently continue to adhere to an outdated image of biology as 'fixed', just when biological theorising itself is experiencing a radical 'social turn' that opens up the possibility for a rapprochement across the great divide between the social and the natural sciences (Meloni 2014).

It is instructive to compare the very different histories of the two, apparently closely related, words 'sympathy' and 'empathy'. Sympathy is an ancient word that has had a place in philosophical discussion since the time of the Greek philosophers. It has been variously deployed over the centuries, giving rise to an accumulation of meanings, some of which are by now strange to us. Prior to an understanding of gravitational forces, medieval astronomers speculated that the planets were kept in their orbits by a force of mutual attraction, which they labelled 'sympathy'. In the eighteenth century, the concept was central to the moral philosophy

3 For an inspired analysis of the problems with this position, see also Latour (1993). 
of Hume (1739-40, 1751) and Smith (1759) (Stueber 2006: 29-31). Empathy, on the other hand, is a relatively modern word. It first appears in English in 1909, as the psychologist E. B. Tichener's chosen translation of the German Einfüblung, literally, a 'feeling into'. Stueber (2006: 5-19) provides an excellent summary of the term's conceptual history in Germany. It was first employed as a technical concept in the philosophical aesthetics of Robert Vischer in 1873 (Vischer 1994), although it already had a longer history within the tradition of German Romanticism, where it was generally used to describe a poetic and spiritual identification with nature. A more direct influence on Tichener, however, was the work of Theodor Lipps (1903-06) on aesthetics. Lipps was concerned to give a psychological account of naturally occurring human tendencies towards aesthetic experience and the making of judgements about the beauty of objects. He argued for an essentially kinetic appreciation of the human body in movement, and of external objects in general, linked to an innate tendency to motor mimicry. Most crucially for present purposes, he further drew a connection between the mimicry phenomenon and our ability to theorise about the minds of others. He thus saw empathy as a necessary and fundamental category of sociology and psychology (Stueber 2006: 7-8).

From the evolutionary point of view, empathy—or the ability to put ourselves in another person's place and thus interpret the minds and moods of others - can be seen as fundamental to the complexity of human sociability (Hoffman 2000). Most recent contributors to the empathy debate agree that it is a complex and multilayered phenomenon. The original insight about mirror neurons was that similar brain activity occurs in observers as well as performers of an action. There is now evidence that mirror systems are involved not only in observing an action, but also in emotional simulation, the observing and generating of facial expressions and shared emotions. Simulation is 'a highly integrated process' involving networks connecting various brain regions to produce a synthesis (Bastiaansen et al. 2009: 2398). But beyond its probable grounding in these neurological mechanisms, which facilitate an initial attunement to others' emotional states, empathy is generally seen to require both affective and cognitive aspects (Baron-Cohen 2011: 12; Gallagher 2012: 356; Stueber 2006: 20-1). Stueber (2006: 20-1), for instance, gives the term 'basic empathy' to 'the theoretically unmediated quasi-perceptual ability to recognize other creatures directly as minded creatures and to recognize them implicitly as creatures that are fundamentally like us'. 
While he sees this as neurologically grounded, he notes that 'we also have to be able to explain a person's subsequent behaviour in a complex social situation' (Stueber 2006: 20-1). He calls the cognitive and deliberative capacities brought to bear to re-enact or imitate in our own mind the thought processes of another person 'reenactive empathy'. Given this interactive and socially situated quality, Gallagher (2012) goes further and proposes that narrative must also play a key role in empathy. This proposition can usefully be integrated into developmental perspectives, since the ability to tell and understand stories, like the development of theory of mind, is also a fundamental human capacity, one that follows a predictable developmental pathway in small children in tandem with the emergence of language. If we accept a definition of empathy as also involving a dimension of caring, Gallagher (2012: 376) states, then for this to happen, the context must be understood: 'empathy depends on A having the right story about B's situation'. At this point, we are back on anthropological terra firma: the study of social context. As Hollan (2008: 484) puts it:

We need to recognize that the kinds of problems and situations people want recognized and understood and the ways in which they seek that recognition will be socially and culturally specific. ${ }^{4}$

Thus, while we may well agree that 'sympathy' is too amorphous and historically polysemous a term to be analytically useful to the social sciences, 'empathy', on the contrary, is a concept that currently has powerful interdisciplinary traction and analytic potential. This would seem to be a promising moment for anthropologists to contribute their own perspectives to the debate, using comparative ethnography to illuminate how other societies theorise about sociality, as well as how they practise empathy or cooperation, and how children actively learn about any such culturally distinctive ethos. The evidence suggests considerable cross-cultural variation in how empathy is expressed (or suppressed), and to whom. Cultural beliefs differ about the essential legibility or opacity of other minds, and hence the possibility of empathising in the first place (Lohmann 2011; Robins and Rumsey 2008), the degree to which ideals of secrecy and concealment may affect the expression of emotions (Throop 2011) or whether individuals may fear that others may abuse empathic knowledge of their vulnerabilities (Hollan 2008, 2011).

4 Clearly, this is variable over time as well as space. On historical shifts in emotional ethos and norms, see Elias (1994) and Stearns and Stearns (1994). 
Hollan, writing of the dialectical aspects of empathy, notes that, among the Toraja, a person may try to hide their emotions for fear that empathic understanding will be used by others to harm them; alternatively, they may beg, cajole or appeal for empathy from the other according to the norms of a socially established 'discourse of persuasion' (2008: 486). Just as humans everywhere share the same neurological potential for language use yet speak different languages, such variation in discourses about empathy and caring for others should hardly come as a surprise.

\section{Learning through ritual}

How do children learn about the ethos of their society? I want to argue here that rituals provide a crucial arena for the absorption of emotional lessons and moral values, not necessarily through explicit instruction but, even more importantly, in a tacit manner, as they observe and gradually join in the activities of adults or become the focus of ritual attention themselves. Besides eventual competence in practical tasks, a great deal of social learning takes place in the ritual context, about kin relations, personhood and morality. Read (1955), for instance, provides vivid descriptions of how, among the Gahuku-Gama of Papua New Guinea (PNG), children learn through the experience of ritual how to 'make their skin good'. This occurs partly in the context of their own initiation rites (which, for boys especially, build to a highly emotional climax in which they are the centre of attention for the whole day). But they also learn through participation in adult rites such as pig feasts, which feature elaborate self-decoration, boasting and oratory. In daily life, too, they are constantly being encouraged to show off, absorbing messages about self-worth and self-expression, as well as about desired physical contact with others who constantly hug and kiss them. The culture thus fosters a certain style of personal expression, one that allows considerable leeway for individual foibles and eccentric behaviour. By contrast, Mageo (2011) provides a nuanced analysis of Samoan children's experiences of empathy (or the lack of it) at the interpersonal level, as those become interwoven with their experiences of ceremonial obligations and the generation of a cultural ideal of collective empathy through ritual. Mageo translates as 'empathy' the Samoan term alofa, standing for 'love', 'affection', but also 'compassion', 'pity' and 'kindness'. Having been showered with alofa by adults as an infant, the small child experiences an abrupt separation by the age of two as it is taught respect for elders and may be rebuked for showing 
off or even seeking physical or eye contact with its betters (Mageo 2011: 75). Children then learn to show alofa by performing service to others, especially within the extended family. Finally, young people experience the extension of alofa to the community level, as they take part in the hosting of travelling parties from other villages (malaga), to whom it is compulsory to offer hospitality. The ceremonial exchanges that take place on these occasions, in Mageo's words, 'flooded participants with what Victor Turner calls communitas - a word I take to mean empathy between groups' (2011: 79). These events, more than anything else, represent a social ideal of shared feelings in action, even if people may sometimes weary of the effort involved or revert to vicious rivalries once the party is over. Another Samoan term relating to empathy (and one of comparative interest in this chapter) is falavelave - the moral imperative to help the extended family, especially in the context of contributing to ceremonial obligations, notably funerals (Mageo 2011: 78). In short, Samoan moral ideals of empathy, Mageo suggests, are much more collectively based than, say, American ones, which tend to be imagined primarily in the context of dyadic relationships.

A collective ethos is especially likely, perhaps, to find expression in funerary ritual. Durkheim, in his Elementary Forms of the Religious Life (1982: 397), wrote of mourning-which he carefully distinguished from individual feelings of 'sadness' - as a collective emotion expressed through organised ritual work. Barbalet (1994: 114), in a more recent discussion, puts it thus: 'Indeed, mourning may be thought of as an organisational emotion that could only be experienced in human society through the application of social means.' Jakoby (2012) contrasts the medical model of grief as an illness from which the individual should recover with its actual occurrence (even in supposedly individualist Euro-American societies) within the framework of family and community relations, where it is also being shaped by cultural and gendered expectations. She draws on Hochschild's conceptualisation of 'emotion work' as 'a gesture of social exchange that is not to be misunderstood as a facet of personality' (Jakoby 2012: 693). In Fiji, as in Samoa, funerals are vital occasions for communal activity. Toren (2006), who elicited Fijian children's accounts of funerals they had attended, considers the effects for them of being exposed to collective norms regarding grieving by adults (which is very public and dramatic) and, further, the more implicit messages absorbed from these performances regarding kinship solidarity. Regarding the formative power of this sort of situated learning, she observes: 
our engagement in the peopled world is always an emotional one, and all our long-held ideas and practices are imbued with a feeling of rightness that goes well beyond any mere rationalization. (Toren 2006: 187)

Weeping and the expression of grief on the occasion of a death are such powerful and binding cultural expectations that they were the most salient feature in the accounts children (aged seven to 13) wrote for her about funerals (Toren 2006: 205-8).

In what follows, that same 'feeling of rightness' can be discerned in Toraja children's assertions about the need to support kin, to feel what others are feeling and to continue traditional practices. These feelings appear to grow directly out of their repeated attendance at rituals, where they witness adult cooperation and, sooner or later, have the opportunity to join in themselves. Some children in my study well expressed the resulting unselfconscious absorption of knowledge about ritual that occurs simply by being present:

I learn from other people by watching those around me when they are carrying out the rite. (Girl, aged 16)

I've seen the way the ceremony is done so I don't need to go to a lot of bother learning what to do, because when the time comes, God willing, I will have further opportunities to take part and I'll be able to do it easily.

(Boy, aged 14)

This mode of learning through participation is, after all, how most cultural knowledge has been passed on, in most times and places. While I had imagined that the children in my study would tell me what they had learned about the practicalities of ritual organisation, I discovered instead that many of them had written about the moral necessity of sharing emotions, whether happiness or sorrow. A more general discussion of my findings is presented elsewhere (Waterson 2015), but in what follows I will focus specifically on themes relating to the emotions, and particularly that of the sharing of feelings as a sort of collective duty. The ideas that were expressed serve to illuminate the process by which Toraja children, through their own experiences in a ritual setting, learn about the wider ethos of their own society and begin to form their own opinions about the responsibilities the system entails, and about their own cultural identity. At the same time, a substantial proportion of children wrote about the anxieties created by the obligations of ceremonial exchange, which create a heavy burden of debt, especially among the poor. Their 
own hopes of pursuing their education are constantly at risk as parental funds are inescapably siphoned towards ceremonial expenditure, and thus they are already in a position to have strong opinions on this matter.

\section{The context of the study}

The Sa'dan Toraja people are a population of around 450,000 living in the highlands of South Sulawesi. The sense of a unitary ethnic identity as 'Toraja' grew partly out of the experience of Dutch colonisation; this part of the highlands became known only in the 1930s as the Kabupaten or regency of Tana Toraja ('Land of the Toraja'). Devolutionary policy in Indonesia since the fall of President Suharto in 1998 has led here, as in many other parts of Indonesia, to a subdivision of previous administrative entities. In 2008, the regency was split into two parts, such that the name Tana Toraja now refers to the southern part, with its main town of Ma'kale, while the northern part, centred on the town of Rantepao, is now known as Toraja Utara (North Toraja). Most Toraja will still insist, however, that in spite of local variations they share the same culture.

The Toraja have long been known for their rich and dramatic ritual life. Mortuary rites, in particular, are famed for their expense and complexity, being celebrated on a spectacular scale, especially by wealthy aristocrats, whose ceremonies may be accompanied by sacrifices of hundreds of buffaloes and pigs. Today, the great majority of Toraja are Christian, leaving perhaps only 5 per cent of the population (mostly older people in remote areas) still adhering to the indigenous religion known as Aluk To Dolo or 'Way of the Ancestors'. While some types of ritual have, as a consequence, become very rare, certain parts of the formerly complex cycle of rites continue to be vigorously celebrated, notably funerals and the rites for inauguration of newly restored or rebuilt origin houses (tongkonan).

In the indigenous cosmology of the Toraja, rituals are divided into two main categories, depending on whether they have to do with the living or the dead. Communal rites designed to enhance fertility and wellbeing, to ward off sickness or to celebrate the renewal of origin houses, as well as those that formerly accompanied the rice-growing cycle, are referred to as Aluk Rambu Tuka' or 'Rites of the Smoke of the Rising [Sun]' and are associated with the east and the deities (deata). Mortuary rites, by contrast, are called Aluk Rambu Solo' or 'Smoke of the Setting [Sun]', 
and are associated with the west and the ancestors. Certain rites fall in between these two categories, enabling a transition from west to east that was intended to end the work of mourning, and, in some areas, was considered to effect a deification of aristocratic ancestors. The Dutch Reformed Church mission, which commenced work in Toraja in 1913, was particularly opposed to the Rites of the East, especially those that involved trancing. At present, with the exception of house inauguration rites (mangrara banua), most of these rites have almost disappeared, while weddings_-formerly very modest occasions_-have become greatly elaborated as a result of Christian influence. The Toraja proved very much more resistant to the mission's attempts to curtail and modify the perceived 'extravagance' of mortuary rites. Funeral rituals today have been Christianised and continue to be performed on an ever more lavish scale. They are undeniably the most conspicuous and salient social events in Toraja life.

In fact, new sources of wealth have been funnelled into the ceremonial economy, causing an escalation of funeral expenditure and a dramatic inflation of livestock prices, which continued unabated even during the Asian monetary crisis of 1997. In my fieldwork with the Toraja, which began in 1978, indigenous religion and ritual life were, not surprisingly, a major focus of interest, and it was impossible not to be aware of the importance of mortuary ritual in social life. Most ethnographers of the region, in fact, have written about funerals, sometimes at great length, and I am no exception. ${ }^{5}$ While my colleagues have tended to focus on the details of the rites themselves or on their ability to attract foreign tourists, I was curious about the organisational complexity of such demanding rites (Waterson 1993). How were decisions made about the numbers of buffaloes to be sacrificed? How exactly did the ceremonial prestation of animals for sacrifice (generally from affines to the children of the deceased person-gifts that must be repaid at a later date) contribute to the maintenance and enhancement of rank and prestige? Historically, it was clear that, in spite of Dutch missionary and administrative disapproval in the early twentieth century, the ceremonial prestation and sacrifice of buffaloes and pigs were so embedded a part of kinship, social and political relations that nothing could persuade people to give them

5 See Adams (1997); Donzelli (2003); Koubi (1982); Nooy-Palm (1986); Rappoport (1999, 2009); Volkman (1979, 1985, 1987); Waterson (1984, 1993, 2009); and Yamashita (1997). Wellenkamp $(1984,1988,1991)$ has focused on emotional aspects of death and grieving, while de Jong $(2008,2013)$ has undertaken the most concentrated study to date of the economics of funerals. 
up. As I continued making regular return trips to Toraja, I tracked the continuing escalation of livestock prices and found myself still pondering the reasons for this extraordinary expenditure, which inevitably places great stress on individual families and often drives people into debt. What has happened in Toraja shows many striking points of comparison with studies of ceremonial economies in PNG societies. Not only do we see the same efflorescence of ceremonial expenditure as money enters the system, but we can also observe that such systems are able to survive wrenching changes in cosmology brought about by conversion to Christianity—something that has radically transformed many PNG societies since the 1960s (Akin and Robbins 1999; Gregory 1980; Stewart and Strathern 2009).

In my conversations with adults about the meanings that ritual performance has for them, they have offered many kinds of insight into the emotional commitments involved and how ritual is bound up with their perceptions of a distinctively Toraja sociality. ${ }^{6}$ What I had never done was to ask children how they learned about the ritual duties they would soon have to assume as adults, and what they thought of this complex and competitive system. Realising that this was a constituency I had wrongly neglected, in 2007, with the help of friends who are retired teachers, I approached the heads of eight middle and high schools in different parts of Toraja and asked permission to carry out a study with some of their pupils. ${ }^{7}$ A total of 451 children agreed to share with me, through writing and drawing, their ideas and experiences of ritual life.

The research followed well-established participatory methods for ethical research with children (Alderson and Morrow 2004; Beazley et al. 2009; Boyden and Ennew 1997; Christensen and James 2008; Ennew 2009). Although children's capacities as informants have often been overlooked or underestimated, they can make excellent research participants and are very capable of expressing useful opinions on matters that concern them. Christina Toren (1993) has argued with particular eloquence that a failure to take children seriously, not just as research subjects but also as human subjects, impairs not only our broader conceptualisations of agency, but also our deeper theoretical understandings of what it means to be human.

6 For a fuller discussion of the Toraja ceremonial economy and its emotional entailments, see Waterson (2009: 395-430).

7 I would like to express my gratitude to Pak Banti (Nene'na Regina) in Rantepao, and to Pak Frans Dengen in Ma'kale, for their help in facilitating the study. 
Children are not just passive recipients in the socialisation process, but are themselves actively producing culture in their social interactions with others. Besides Toren's work in Fiji, Laurence Goldman's (1998) innovative study of children's play among the Huli and Lyn Parker's research on children and schooling in Bali $(1997,2002)$ provide further excellent examples of how children's own developing cultural perspectives can yield vital insights into cultural processes in general.

\section{Children's perceptions of ritual}

With the permission of principals and teachers, I visited classrooms and elicited children's participation in answering my questions. The schools visited were a middle school (Sekolah Menengah Pertama, SMP) and a high school (Sekolah Mengah Atas, SMA) in each of four areas: two rural locations, Sa'dan in the north and Mengkendek in the south, whose pupils tend to be drawn from the immediate vicinity; and the two towns that form the administrative centres of the regencies, Rantepao (North Toraja) and Ma'kale (Tana Toraja). The town schools have generally higher standards than those of outlying areas and accept pupils from many different districts. There was a preponderance of girls in the sample (278 of 451, representing 61 per cent of middle schoolers and 62 per cent of high schoolers). This is due to the fact that more boys than girls opt to attend the parallel technical schools at each level, rather than the mainstream schools. The ages of the middle schoolers ranged from 10 to 16 , the majority being 14 , while the high schoolers' ages ranged from 15 to 19 , the majority being 17 years old.

All the responses were written in Indonesian, the language the children are accustomed to using in school, although Toraja is still spoken at home by most families. Regrettably, this means that the study failed to shed light on specifically Toraja vocabulary for the ideas the children expressed, although there is no doubt that some of these ideas are distinctively Toraja in character. ${ }^{8}$ I did not ask children to state their religious affiliations, but, given the dramatic decline of Aluk To Dolo in the areas studied, and the

8 A key Toraja term for mutual caring is sikaboro', which is often used by adults in the western part of Toraja where I lived during my fieldwork to explain why, in that area, they prefer to refrain from driving each other to ruin through competitive excess in funeral sacrificing. Another term for love, with an emphasis on its compassionate aspect, is mamase, while mali' ('to want, desire'), when used in the phrase mamali' lako, carries the sense of longing or 'yearning towards' another person, sometimes specifically by an inferior to a superior (Donzelli 2003). 
fact that schools have long been a major locus of Christianisation, it can be safely assumed that all the children in my study are at least nominally Christian. Another difficulty in interpreting the results is to know precisely how far the responses are influenced by the children's exposure to Christianity, although this influence is obviously present in some of their responses and reflects the current situation in which, for a majority of the population, Toraja identity is already bound up with being 'modern' and Christian, while the indigenous religion is perceived as oldfashioned, in spite of people's continuing investment in the performance of Christianised rituals. It is noteworthy that only five children voiced religious objections to rituals per se (see Appendix Figure A4.4). ${ }^{9}$

\section{Age distribution of children}

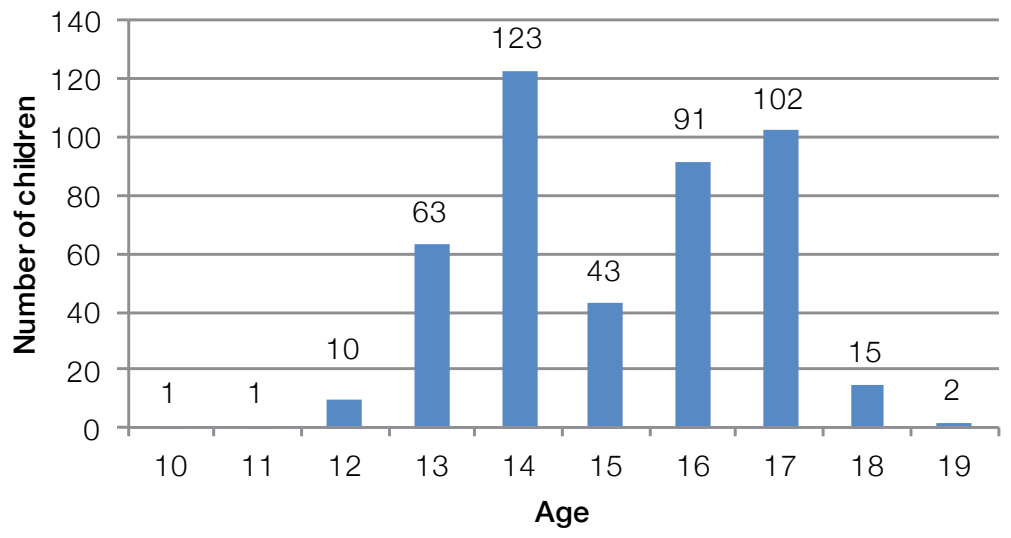

Figure 4.1 Age distribution of participants

Note: $\mathrm{n}=451$.

Source: Author's data.

A simple and graphic consent form was given to each child and it was made clear that participation was voluntary. Drawing paper, crayons and felt pens were provided for those who wished to draw pictures related to their experiences at rituals. Before beginning, I explained my own longterm research interest in Toraja ritual life and my awareness that adults

9 It is conceivable that some of these children were Pentecostalists, since this sect forbids participation in funeral sacrifices, but, if so, none of them mentioned the fact. Only one child in my study mentioned the existence of this Pentecostal prohibition in general terms. Pentecostal churches (of which up to 20 are now represented in the highlands) have won the most converts in southern districts, where the status system is most rigid, since they offer a way out of the ceremonial system to those who can least afford its demands (de Jong 2013: 205-9). 
held a range of opinions about the ceremonial system. I emphasised that there were no 'correct' answers, but that I valued their opinions and they were free to write whatever they wanted. The questions I asked them to write about were the following:

1. What ceremonies have you attended?

2. Whom did you go with?

3. Describe a ceremony you have attended and what was done there.

4. What is the purpose of that ceremony?

5. What did you learn from attending the ceremony?

6. What will you do when you are grown up if someone in your family is having a ceremony?

7. Is there anything else you would like to tell me about ceremonies in Tana Toraja?

The children's responses to these questions were coded for emergent themes, which were then consolidated into a smaller number of categories and analysed using SPSS Statistics. Tabulated results are shown in Appendix 4.1. In what follows, I discuss certain themes that revealed emotional content and examine more closely the content of selected individual responses. I was interested to see how far the content or elaboration of answers might differ between the two age groups. It transpired that only one 10-year-old, one 11-year-old and ten 12-yearolds participated in the study, so I am unable to say anything conclusive about how the ideas of pre-teenagers might differ from those of teenagers in the study. But, in general, while some of the middle-schoolers (including these youngest participants) gave very brief and simple answers to my questions, the responses of others were just as articulate as those of the older teenagers, and the themes they expressed turned out to be very similar across both groups.

Reviewing the data, the first thing that leaps to attention is the extraordinary salience of funerals compared with any other ritual event. In stating what rituals they had attended, most children named rites of both east and west; but, when asked in Question 3 to choose one of them to write about, an overwhelming majority elected to write about funerals. Slightly more girls than boys selected a Rite of the East (house ceremonies, weddings and, once or twice, a birthday party-a very recent innovation), but, in all, 401 of 451 children, or 89 per cent, elected to write about funerals and only 33 , or 7 per cent, about other rituals. A further 12 of 
451, or 3 per cent, wrote of their attendance at rituals of both the east and the west, while five (1 per cent) gave no answer. We can assume that not only had all the participants attended funerals multiple times, but also the rite was taken by many respondents to be the most distinctive feature of their culture-one they wrote about with considerable pride. House ceremonies (mangrara banua) are celebrated only by families of noble rank and they take place at much longer intervals; but funerals happen all too frequently, and it is a compelling social duty to attend them. What the children's responses chance to reveal, then, about the emotional dimensions of ritual has to do chiefly with their understandings of mortuary ritual.

\section{The purposes of funerals: Shared feelings and the theme of consolation}

In response to Question 4, regarding the purpose of the ceremony they had chosen to write about, most children offered multiple answers. Various ideas were put forward to explain the purpose of funerals. Most prominent was the idea of duty to one's kin and, more specifically, to show respect to the deceased person themselves (mentioned by 41.9 per cent of children), followed by the need to uphold tradition, culture or adat ('custom') (30.7 per cent). Rituals provided occasions for kin to gather together, according to 24.1 per cent. Another frequently mentioned the idea was that sacrifices help the deceased to reach the afterlife (28.9 per cent). This is a noteworthy finding, in the face of the apparently drastic changes of cosmology that have been entailed in the conversion to Christianity. According to the Aluk To Dolo, when a person dies, an aspect of their soul, called bombo, travels to Puya, an afterlife far away in the south-west, where life continues to be lived in much the same way as on Earth, but without fire. Animals also have bombo, and those of the buffaloes and pigs slaughtered at the funeral are supposed to follow the dead person to Puya to provide for their needs in the afterlife. Thus, those who are wealthy on Earth and have many descendants to sacrifice for them will continue to enjoy a comfortable life in the hereafter. The Dutch Reformed Church preached a quite different vision of life after death, yet the socially binding requirement to sacrifice has survived and, to some extent, so has the cosmological rationale for it. Somehow, sacrifice is still seen as assisting the soul's transition. The blending of cosmologies is reflected in what children wrote, for some of them used the traditional 
Toraja name for the afterlife, Puya, while others used the Indonesian term surga to refer to the Christian 'heaven', or said the deceased would be 'received at the right hand of God', would 'rejoin their Creator' or would be helped by the sacrifices to 'get to the Almighty [Yang Maha Kuasa] quickly and safely'. Others used the more neutral term alam baka to refer to 'the afterlife' or even described the soul's destination as 'nirvana'. Taken together, their answers indicate considerable ingenuity in integrating the various opinions they may have heard from adults about the reasons for mortuary sacrifice. Indeed, 12.6 per cent named sacrifice of livestock as being in itself the chief purpose of the funeral rites, while an almost equal proportion (11 per cent) also mentioned the status dimension of sacrifice (which by adults is seen as the culmination of the deceased's career) with answers such as the following:

Sacrificing buffaloes is part of Toraja culture because it represents the final duty [bakhti terakhir] towards our parents, and if someone gives us a buffalo or pig that becomes a debt of honour [utang budi] that we owe to that person. (Girl, aged 14)

The buffaloes that are sacrificed indicate the rank of the person who has died. For instance, if the buffaloes killed are many, and among them is a spotted buffalo [tedong bonga], that means that the deceased is a prominent [terpandang] person in their area. And the converse also applies. (Girl, aged 14)

A distinctive set of answers expressed the cultural requirement to share the grief of those who have been bereaved or described the funeral rites as providing consolation or entertainment for those involved. The need to 'share sorrow' was mentioned by 14 per cent of children. Some used conventional Indonesian turns of phrase for the expression of condolences, while others chose imagery that is more characteristically Toraja:

The point of the ceremony is to share each other's sorrow [saling membagi kedukaan]. (Girl, aged 14)

The purpose of the ceremony is so that people can join in expressing their condolences [turut mengungkapkan bela sungkawa mereka]. (Girl, aged 14)

It's to strengthen kin ties, and also we can meet our relatives and share in the grief they are feeling [saling merasakan duka]. (Girl, aged 14)

The point of the ceremony is to share in the sorrow over the death of a family member and besides that, the family also wants to share whatever they have even though they are in a state of mourning. (Girl, aged 16) 
The purpose of the ceremony is to uphold our customs and traditions so the young people nowadays won't forget them, and maybe also to cast away all sadness by sacrificing buffaloes [menghempaskan semua kesedihan dengan cara memotong kerbau]. (Girl, aged 14)

The purpose of the ceremony is so that the person who has died will see how sad all their family and friends are when they recall the person's life story. (Girl, aged 14)

In the last three examples, we see that the sharing of feelings is conjoined with the sharing of material goods in staging the rituals and engaging in the expected ceremonial exchanges. The idea that sacrificing enables the 'casting away of sadness' echoes adult ideology. It is an explanation often given by adults, and a distinctively Toraja cultural trope, that sacrifice serves to 'take the place of our sorrow' (ussondai pa'di'ki) at a bereavement and relieves feelings of grief (Waterson 1993). The idea that the deceased person is still present, able to watch the actions of their kin and witness their grief is also in accord with traditional conceptions, while the mention of recalling the person's life story relates to the performance of the funeral chant, ma'badong. For the highest-ranking funerals, an effigy (tau-tau) of the deceased is made. ${ }^{10}$ In the old days, the making of this effigy was accompanied by offerings and it was considered that the bombo inhabited the effigy until the completion of the rites. Only after the burial would the bombo set out on its journey to Puya; until then, it would be enjoying the festivities prepared for it. During the rituals, the tau-tau would be placed in the centre of the slowly rotating circle of dancers who, throughout the night, would perform the ma'badong. In part of the litany, the deceased's life story is related, improvised by the song leader, who draws on a stock of poetic imagery, expressed in paired lines of verse. Several other responses also mention the ma'badong, which remains an indispensible part of the proceedings. Its function is clearly stated here as entertainment, whether for the deceased or for the grieving relatives. Dana Rappoport $(1999,2009)$ has written searchingly of the significance of group vocal performances whose sensory effects serve to create the special atmosphere of rituals, whether of the west (ma'badong) or of the east (where a parallel kind of

10 The Toraja Church (Gereja Toraja) tried hard to ban the tau-tau as idolatrous, and, in the early 1980s, the controversy over this issue was extremely divisive. The bid failed, however, and, nowadays, the practice continues in a desacralised form. After some Toraja carvers went to Bali and studied with Balinese woodcarvers, there was a change in the style of tau-tau. Once highly stylised, the statues are now made as lifelike as possible. Instead of becoming a potent image of the dead as ancestor, it is rationalised that the statue is nothing more than a commemorative portrait, the equivalent of a photograph. 
performance, with different words, is called ma'simbong). At larger events, it is common for several groups to perform, sometimes simultaneously but in competition rather than in concert with each other. The 'thick' melismatic aural texture produced by the singing creates its own peculiar, immersive atmosphere, both mournful and pleasing - an effect that is touched on in the last comment in the quotes below:

Everything that is done in the funeral rite, the ma'badong dance among other things, has a purpose, which is to please and entertain the soul of the deceased. (Boy, aged 17)

Ma'badong is like a lullaby to soothe the deceased so they will sleep peacefully. (Girl, aged 15)

Ma'badong is a sad song to cheer the hearts of those who are in mourning. (Boy, aged 16)

I can feel the sadness and loss of the person who has died through the waves of sound created by the ma'badong singers [lewat alunan orang yang ma'badong]. (Girl, aged 14)

Here we touch on a distinctively Toraja interpretation, emergent also from other responses, which holds that the point of the funeral proceedings is to provide entertainment or consolation (penghiburan). This applies not only to the ma'badong, but also to the more spectacular aspects of highranking funerals, such as making the buffaloes fight each other before they are sacrificed (mápasilaga tedong). Some 13.1 per cent of children wrote that the point of funerals (and, hence, the duty of those taking part in them) is to console or distract (menghibur) the bereaved family, the guests and/or the soul of the deceased. Although 'console' is in fact the primary meaning of this Indonesian verb, the noun penghiburan is more commonly used to mean 'distraction', 'recreation' or 'entertainment'. This borrowing from Indonesian is not a direct translation of any Toraja phrase, since in Toraja the more traditional expression would be undampi pa'dinna, 'to heal/provide medicine for their pain'-a reference to the heartache (pa'di penaa) of bereavement. However, the idea that ritual represents a particular combination of 'work' and 'play', and that the playful part is actually intrinsic to the ritual's success, is a theme that is evident not only among the Toraja but also in many other Austronesian cultures. This is something about which I have written elsewhere (Waterson 1995); a comparative example will also be found in Sather's Chapter 3 in this volume, which describes the essential role of play, beauty, entertainment and pleasure in an Iban shamanic curing ritual, the Sugi Sakit. As he puts 
it, this aesthetic emphasis was 'not incidental to the purpose of the [rite], but, rather, contributed directly to the ritual's effectiveness'. He makes some searching comments about the potential importance of this aspect of entertainment even (or perhaps especially) in the context of illness or death, as a means of asserting the extension of the person out into the wider world. In the face of death, with its entailments of grief, loss and the reduction of ties, the mobilising of the community, 'motivated by shared feelings of compassion', works to counter that sense of loss by creating a spectacle in defiance of the social disruption that death entails.

On this note, some children further stated that the whole point of the event was to be festive, expressing the culturally salient idea that there is pleasure in seeing festive crowds gathered together. This is reflected in the positive associations of the Toraja word marua, which corresponds to Indonesian ramai ('noisy, cheerful, crowded'). One person also wrote that the funeral rite ensures the family will be prosperous and well (sejabtera), reflecting a traditional belief that generous sacrificing brings blessing and long life to the sacrifier (Waterson 2009: 396).

[The purpose is] to entertain the family of the deceased. (Boy, aged 17)

[The purpose is] to entertain the Toraja people with buffalo fights. (Girl, aged 14)

The point of the ceremony is to make the ceremony more festive [memeriahkan pesta tersebut]. (Girl, aged 14)

Our reason for holding the ceremony is to see people being ramai-ramai. (Girl, aged 10)

[The purpose is] to cheer us up so we won't be broken-hearted in our sadness. (Girl, aged 15)

[The purpose is] to entertain the family that has been left behind so that they will not be overwhelmed by their grief [tidak larut dalam kedukaan; lit., 'will not dissolve in grief']. (Girl, aged 16)

The last two responses point to other culturally specific reasons for such a priority being placed on providing distractions for the grieving family, since excessive mourning is considered potentially dangerous to one's health (Hollan and Wellenkamp 1994: 200; Wellenkamp 1988, 1991: 129). 


\section{Learning through ritual participation}

When asked what they had learned through participation in rituals (Question 5), the children's most common answers concerned not so much education in practical tasks, but kinship and the moral necessity to work together. Among the responses, 53.3 per cent spoke in general terms of learning about their 'culture' or 'the way things are done', while 38.5 per cent wrote of the importance of working together and 34.2 per cent of the strength and value of kin ties. The requirement to share the feelings of others was specifically expressed by 10.9 per cent, or 48 of the 451 children. Many children gave multiple answers, such that their placing of these features in combination builds up a picture of a moral universe of mutual support and shared feeling, leading naturally to the sharing of work and cooperation, which, in turn, serve to constitute kinship solidarity and, ultimately, the feeling of being Toraja:

I've learned to urge myself to feel what the bereaved family is feeling [mengajak diri untuk merasakan apa yg dirasakan oleh keluarga yang berduka]. (Girl, aged 17)

I've learned to share the grief of the bereaved [turut berdukacita]. (Girl, aged 14)

I've learned to join in feeling the sorrow [turut merasakan kesedihan]. (Boy, aged 16)

I've learned how strong and close the kin ties in our family are and also how to share sorrow [saling membagi duka]. (Girl, aged 14)

What I've learned from going to funerals is to share in feeling the sorrow of the family who have been left behind [by the departed]. (Girl, aged 17)

I've learned to join in feeling what others are feeling, so that we can help each other. (Girl, aged 17)

There is a really great feeling of love for the family of the person who has died. This is shown in the relatives' willingness to lay out so much money to sacrifice pigs and buffaloes. (Boy, aged 14)

One thing we can learn from ceremonies is the strength of family feeling between the bereaved family and the guests, because the guests usually bring buffaloes, pigs or cakes to express their shared sorrow with the bereaved. (Girl, aged 16) 
We must care for each other, whether at times of happiness or sadness. At these times, we can share the feelings that they are feeling, whether happiness or consoling those who are grieving [menghibur yang berduka]. (Girl, aged 16)

The theme of helping each other was repeatedly expressed. While some focused on empathy with the bereaved, others described learning to join in with specific tasks. This is described by some as helping to lighten the burden of sorrow and, by others, in terms of a broader social principle of cooperation:

We learn from our parents how to serve the guests with food and drink. (Girl, aged 10)

I learned how they slaughter buffaloes and roast pigs. (Boy, aged 12)

I helped people wash dishes and they were very pleased because someone helped them. (Girl, aged 16)

When there is a ceremony everyone works together without being forced, and all have different jobs to do ... e.g. I have joined in helping to wash dishes and sweep the guest shelters, even when I was little. (Boy, aged 16)

People cooperate to help the family in mourning, for instance by helping with the cooking or building guest shelters. (Boy, aged 18)

I've learned that work gets done quickly when we work together. (Boy, aged 17)

From funerals I've learned that we can help and work together to lighten the burden and share the grief. (Boy, aged 16)

I've learned the feeling of togetherness and cooperation while doing heavy work, for instance in mápalao [the procession that carries the corpse in its bier on its final journey to the tomb] we all pick up the body together to carry it out, so as to please the soul of the deceased. (Boy, aged 17)

This theme of cooperation as a cultural value or moral requirement was often expanded into more generalised statements, sometimes including mention of kinship bonds, but often expressed simply as a fundamental characteristic of Toraja society:

If there is work to be done, it must be done cooperatively. (Boy, aged 13)

By taking part I've learned that we must help each other in every task.

(Girl, aged 14) 
What I've learned is to urge myself to help others and in helping each other we come to know that this is our adat in Toraja. (Girl, aged 17)

I have learned about feelings of togetherness in the community and being friendly [beramah-tamah]. (Girl, aged 16)

We can develop the feelings of cooperation within the community and become aware that humans can't live without the help of others. (Girl, aged 15).

By taking part we can see how great is the feeling of mutual assistance, tolerance and sympathy [gotong royong, toleransi dan simpati] among the Toraja people. Besides that, the ceremony shows the togetherness and close kin feelings among members of the tongkonan. (Girl, aged 16)

I've learned that there is a very good feeling of cooperation in carrying out a ceremony because all the family whether close or distant relatives will come and help, in short the family feeling that Toraja people have is very strong, to pray that the soul will be saved. (Girl, aged 16)

And in the matter of participation, it's a very beautiful thing how if there is any organisation or activity going on, people will come and help even if they are not family, but they know about kinship in our beautiful and prosperous Tana Toraja. (Girl, aged 17)

In the following examples, the theme of the necessity of cooperation is touched on in relation to a more practical aspect-namely, the competitive nature of the ritual system within which a family's own performance will be judged. The challenge of organising such a complex and expensive event, and the difficulties it may pose to kin in marshalling the necessary resources, is particularly clear in the third statement:

The children of the deceased must try their utmost to sacrifice pigs and buffaloes, because the rank of the family can be seen from how many pigs or buffaloes are sacrificed. (Boy, aged 17)

I can see which families have profited and done well on the rantau, so much so that it becomes a motivation to me as well. (Girl, aged 17)

It's clear that funerals in Tana Toraja are considered so sacred ... and we must really prepare ourselves as well as we possibly can if we are to hold such a ceremony, and the family must stand shoulder-to-shoulder to support each other ... because this ceremony will really drain our strength and ingenuity [sangat menguras tenaga dan pikiran kita]. (Girl, aged 13) ${ }^{11}$

11 Menguras means, literally, 'to flush out a drain'. 
Some children wrote of what they had learned about etiquette and politeness in social interaction-often expressed as paying attention to or showing respect for each other's feelings. They noted further that ceremonial occasions provided important opportunities to learn to know a wider circle of kin, including migrants who might be returning home from distant places:

I learned how to receive the guests and how to behave when I meet other people. (Girl, aged 15)

I have learned how to cooperate with others, to be polite and help those who are working. (Girl, aged 13)

I have learned how we should respect those who are older than we are. (Girl, aged 14)

I've been taught how to serve the guests nicely, and I've also learned the customs of my area such as that one must not turn one's back on people while eating. (Girl, aged 13)

I've learned that there is an attitude of mutual respect between the guests and the hosts of the rite. (Girl, aged 16)

We must take care of each other [peduli kepada sesama], and most especially of our kin. (Boy, aged 17)

I've learned that there is an attitude of looking out for each other [adanya sikap saling mengingatkan]. (Boy, aged 16)

What I have learned is that we must know all our kin so that the bonds of kinship will always remain strong and we shall maintain our closeness and unity. (Girl, aged 13)

We can learn about other families [or family members] because during the rite the family's genealogy is often explained. (Girl, aged 17)

I have got to know my distant relatives, and even the closer ones that I hadn't yet met. (Girl, aged 13)

I have got to know family members coming from various cities. (Girl, aged 14)

I have learned to know my kin, especially those we see rarely, because those who are away on the rantau [i.e. migrants living outside the homeland] will return, and we will meet them. (Girl, aged 17) 
A few children also mentioned that taking part in these public occasions had in itself been an experience or had made them feel more socially confident. When asked with whom they had attended rituals, the majority named their immediate family ( 40 per cent), extended family (16 per cent) (often including long lists of categories of relatives in their answer), 'family and friends' (31 per cent) and 'family, friends and neighbours' (10 per cent). But some (2.7 per cent, mostly boys) mentioned going alone. This is not an innovation, since these are the social events par excellence; they were even more important traditionally in providing one of the few socially approved opportunities for young people to see and meet each other. The last comment below indicates that they may still be serving that function, even today when young people have many more opportunities to meet, at school and elsewhere:

[I have learned to] be more self-confident [percaya diri]. (Girl, aged 13)

I have learned about these ceremonies and that has also been an experience in my life. (Girl, aged 14)

We can take part in different places without having to have anyone accompany us. (Girl, aged 13)

Not surprisingly, some of the children's responses reflected newer ideas about attitudes to death and the purposes of the funeral ritual, some of them doubtless derived from listening to Christian sermons. Calvinist doctrine can hardly be said to have lightened the load when it comes to dealing with grief; perhaps it has even accentuated it by introducing worries over sin and salvation:

Even though the person we love is gone, we must still be steadfast [tabah], and continue to praise and give thanks to God. (Girl, aged 14)

I've learned to work together to pray for the relative who has died, so that they will be received at God's side. (Boy, aged 16)

I have learned that in this world it is certain that all people must die. Therefore we must use our time as well as we can, for instance by doing good to everyone, so that when we die there will surely be many people who will join in mourning us, and our good deeds will live on and be remembered for ever, and in the afterlife we shall get our reward. (Boy, aged 14)

We must be steadfast in facing everything and learn not to be too carefree [tidak terlalu bersenang-senang] because a moment will come when we will experience a sorrow we were not expecting. (Girl, aged 13) 
In Question 6, children were asked what they expect to do as adults if someone in their family is holding a ceremony. I was seeking to learn more about their views of the ritual responsibilities that lie ahead of them, and how far they envisaged themselves becoming involved in the ceremonial system. I also expected that the question might shed light on whether any of them might, on the contrary, wish to limit their engagement with it. Their answers once again brought to the fore the importance of shared feelings, specifically within the family. The identification with the family and its reputation in some responses extended into the claim that this is a distinctively Toraja characteristic:

I will try to join in attending every funeral as a sign that I share the sorrow [turut berbela sungkawa]. (Girl, aged 15)

I will attend the ceremony from the first day to the last. (Boy, aged 14)

I will share in happiness or in sorrow (join in feeling whatever the family is experiencing). (Girl, aged 19)

I will join in sharing sorrow, I will join in sharing joy, and I will join in taking a role in the ceremony. (Girl, aged 14)

I will join in with whatever the family is doing, feel whatever they are feeling, and help them in any way I can. (Girl, aged 18)

We must help the family in all sorts of ways because who else will help us if not our close family? In my view, people can't live without the help of others, and if we ever suffer a misfortune, they are the ones who'll help us. Because in my opinion Toraja adat is strongly bound up with the ties formed by working together and helping each other. (Girl, aged 17)

I will join in helping so that all the work of the ceremony will be done well and reflect our family feeling [rasa kekeluargaan]. (Girl, aged 17)

I will participate because I am part of the family, so I must show an attitude of family feeling [sikap kekeluargaan] because family feeling is a special characteristic of Toraja people. (Girl, aged 17)

Many answers expressed formulaically the social compulsion to contribute to ceremonies, with phrases about helping 'materially and physically', 'materially and spiritually', 'with labour and goods' or 'with labour, time, thoughts and materials'. Thinking was mentioned often as a necessary contribution to planning, so that the complicated rite would go smoothly 
and bring credit to the family. These responses—categorised for purposes of analysis under the heading 'Help in any way I can'-accounted for 46.9 per cent of all responses. Some examples follow:

If I am given a job to do, I will strive to ensure that whatever task has been entrusted to me is carried out properly. (Girl, aged 17)

When I am grown up I will automatically do what's expected, for instance carrying pigs, serving cigarettes to the guests, killing pigs and joining in the mábadong. (Boy, aged 17)

I will do anything I can to help the family and ensure that the rite goes smoothly. (Girl, aged 17)

I will help with: labour, time, thoughts and materials. (Girl, aged 14)

I will contribute my time and labour; materials to prepare for the rite such as money, livestock such as pigs, and I shall help the women cook in the kitchen. (Girl, aged 14).

I will help by contributing my thoughts [sumbangan pikiran] so far as I am able so that the ceremony will be well planned and carried out. (Girl, aged 15)

I have to help others with whatever I have, whether we have goods or things or anything at all that we have, we have to give it to our kin, e.g. at funerals we can give either a buffalo or a pig. (Girl, aged 17) [It is noteworthy that this girl, in her response to Question 7, was also critical of excessive funeral expenditure.]

Besides helping in this generalised way, 37.7 per cent of children stated more specifically that they would try to contribute a pig or buffalo for sacrifice if they could afford it. The following examples strongly express the felt necessity to contribute to the ceremonial system, and some children even envisage migrating (merantau) to earn money for this purpose, while others express reservations about the risk of exceeding one's means:

I will contribute pigs and buffaloes with a pure heart and without being forced to [tanpa paksaan]. If I have no livestock or money to contribute I will still attend; just attending is already sufficient to strengthen the bonds of kinship. (Boy, aged 15) [This answer expresses the cultural maxim that attendance in itself is already a virtue, and that it is better to attend, even with nothing to bring, than to stay away for fear of coming empty-handed.] 
I will join in sacrificing buffaloes and pigs because this is my responsibility as a Toraja person and I must do it because this is the expressed wish of my deceased family members. (Boy, aged 16)

I will participate for instance by sacrificing buffaloes or pigs even though it's very expensive, but the thing is, family members must help each other. (Girl, aged 17)

I will take part without having to be forced, as far as my means allow. I will give whatever I can afford without interfering with my primary needs. (Boy, aged 17)

The help I shall give will not be in the shape of pigs or buffaloes, but money, because it will be more useful. (Boy, aged 16)

To follow the adat and sacrifice buffalo you need a lot of money. First of all I will look for work, then when I have earned lots of money I will come back to Toraja. (Girl, aged 15)

I will attend because whatever I may think, I am still a Toraja, so I must take part even if I think it's all a lot of fuss about nothing [hura-hura belaka: 'just noise']. From another point of view, this is our tradition passed down by our ancestors. So we must carry it on [lit.: 'these are their shoes, which we must put on and walk in them'], so long as we are able and can afford to. (Girl, aged 17)

\section{The ritual dilemma: Debt, anxiety and the desire to lessen the ceremonial burden}

The darker emotional side of Toraja mortuary ritual is the danger of being financially overstretched and driven into debt, and the resulting anxiety attendant upon trying to meet one's obligations. Children inherit land rights and property from their parents, but they also inherit any unpaid ceremonial debts, which thus pass down the generations. Added to this is the difficulty of refusing a gift of sacrificial livestock from an affine without causing serious offence and rupturing the relationship, so that every funeral creates a new round of debts to be met in future. Managing the ceremonial demands upon a family's resources certainly gives adults cause to worry; one woman friend told me that, in an entire lifetime spent raising pigs for the household, she had never been able to sell a single one, since as soon as she had one large enough to sell, it would inevitably be 
needed to repay some ceremonial debt or other. Children likewise showed that they are already aware of these problems, and some clearly hope to find ways to limit their expenditure:

Ceremonies in Toraja are so impressive, but there are some people who think otherwise, for instance, they say Toraja people are never sincere about giving; if they take a buffalo to a ceremony they even expect it to be repaid and then you'll be looking for money the whole year just to use it up in one moment at a ceremony. But it depends how you look at it. As for me, since I'm Toraja, I always support the holding of ceremonies in whatever form. (Girl, aged 14)

In my view Toraja ceremonies are pretty extravagant because we have to bring pigs or buffaloes. And if someone dies and a member of our family has ever been given a buffalo then we have to pay it back at the funeral by bringing them a buffalo too. And if we haven't enough money to buy one, we shall certainly go into debt to someone else in the process. (Girl, aged 14)

Everyone who is of Toraja descent is sure to want to carry out Toraja traditions/adat fully if they can afford it, and it's the same with me. I should like to take part in the adat for instance by bringing buffaloes or pigs, but I shan't cut too much, but in accordance with what I can afford. (Girl, aged 15)

I will refrain from giving buffaloes to a poor family because it will be burdensome for them-I will give them what they most need. (Boy, aged 16)

I will take part in accordance with what I can afford. I will not force myself to spend more than I can afford, because I am sure that even the person who has died would not agree with that. How much better it would be if those resources were spent on furthering one's education and saving for the future. (Girl, aged 17)

I will not force myself to buy pigs or buffaloes that I really can't afford. I don't want my children's education to be ruined because of our customs. I don't mean to disavow Toraja culture. But culture must be tailored to our means. (Boy, aged 17)

I will still participate, on the condition that I will not hold ceremonies that are extravagant. If someone in my family dies I will still strive to honour Toraja culture but I will also try not to be trapped in it [terjebak di dalamnya]. (Boy, aged 17) 
When I am an adult I will keep to the adat. But I shall do my best to minimise the family's debts, so as not to burden the next generation. These debts can be passed down from generation to generation. So, in order that the next generation should not have to struggle to repay their debts, the older generation must reduce the debts they incur. (Girl, aged 16)

I value our adat which represents our cultural wealth which attracts tourists. But I think more about the future when it will be harder and harder to meet our needs, and I imagine how that will get even harder if we are involved in the business of reciprocal exchange and debt [utangpiutang]. I am determined not to create new debts except with very close family. And I intend to pay off my parents' remaining debts so that there won't be any more of them. This doesn't mean that I hate funerals, I still love the culture because besides the system of debts there are other things that we can be proud of in the mortuary rituals, and I shall still want to attend them, and I will help bring drinks to the guests and join in the ma'badong, or meat divisions, so as to perpetuate Toraja culture. (Girl, aged 15)

Question 7 was entirely open-ended, simply asking, 'Is there anything else you would like to tell me about ceremonies in Tana Toraja? In all, 282 of the 451 children (or 62.5 per cent) chose to answer this, providing further details and commentary on a number of aspects of ritual. The subjects on which they chose to elaborate revealed a certain amount of ambivalence about Toraja culture. Striking above all was the intense pride expressed in the 'uniqueness' of Toraja culture (mentioned in 128, or 45.4 per cent of, responses) and the necessity of preserving it (109, or 38.7 per cent of, responses). Again, the festive drama of rituals was stressed as an admirable and distinctive feature. Of the responses, 77 (or 27.3 per cent) explained various aspects of the funeral rituals as being manifestations of rank and status; and 17, or 6.2 per cent, also mentioned that their culture was sufficiently extraordinary as to attract international tourists. Some made the point that Toraja was a peaceful area (implicitly drawing a contrast with other regions that were afflicted with outbursts of ethnic violence in the years immediately following the fall of Suharto):

There are many fine things about our culture that are unique and sacred. (Girl, aged 14)

Toraja ceremonies are only for Toraja people, so they cannot be carried out in other areas. (Boy, aged 13) 
In my opinion ceremonies in Tana Toraja are already pretty terrific as far as the Toraja people themselves are concerned [pesta di Tana Toraja sudah cukup maksimal bagi masyarakat Toraja sendiri]. (Boy, aged 16)

There is no ceremony more festive [meriah] than a Toraja funeral. (Boy, aged 14)

Ceremonies in Tana Toraja are very festive [sangat ramai] ... whenever there is a ceremony, especially funerals, people are always sacrificing buffaloes and making them fight. Our ceremonies are really festive. (Girl, aged 13)

It's clear that ceremonies like this are not to be found in other places, only in Toraja. They are unique and different from everyone else's. That is why we must be proud of Toraja. (Girl, aged 14)

In my view ceremonies in Tana Toraja are very unique and extraordinary, such that they have become famous and attracted much attention from people of other countries, and also Toraja traditions and customs are not like those of other areas, hence our culture is more different. (Girl, aged 14)

In my opinion, Toraja adat is very unique and should be preserved [diabadikan]. Even though most rituals in Tana Toraja are very expensive. However that may be, I am extremely proud to live here and to be Toraja. I LOVE TANA TORAJA. 'Misa' kada dipotuo, Pantan kada dipomate.'12 (Girl, aged 14)

I hope you like Toraja ceremonies, whether of the West or of the East, because in them you can see a lot about Toraja culture which is unique and very impressive and different from other cultures. I hope Toraja culture will not be lost or fade away and will continue to attract tourists to come here. (Girl, aged 15)

TANA TORAJA is very, very beautiful, it has lovely landscapes, there is rarely any unrest, not like other areas, its people are friendly and help each other and they cooperate in everything. Another thing is that Toraja people always do their best to work hard so as to pay off their debts. I am proud to be a Toraja person. (Girl, aged 14)

12 A traditional saying meaning: 'Let agreement be upheld and discord be done away with.' This refers particularly to the ideal maintenance of harmony within the family (by no means always achieved in practice, since almost all disputes in Toraja are over land and inheritance issues, and occur between family members). Here, it is implicitly extended to characterise Toraja culture itself as peaceful and harmonious. 
The culture of TORAJA is very unique, and for this reason, TORAJA ceremonies whether of the West or of the East must continue to be preserved and perpetuated so that TORAJA will always possess its special culture which reflects the [cultural] richness of TORAJA. (Girl, aged 16)

These comments are remarkable for the extent to which they reveal a highly self-conscious sense of ethnic identity among the young. Although the very idea of a distinctively 'Toraja' ethnic identity has been a relatively recent process, set in motion in the twentieth century, and one that is still unfolding today, the writers clearly see themselves as carriers of a unique cultural identity, positioned within the modern Indonesian state and the wider world. One might ask whether the extent to which this identity is presented as being bound up with rituals, and funeral celebrations in particular, is an artefact of the kinds of questions I was asking, or whether the evident pride expressed in being Toraja was simply a response to having a foreign researcher in the classroom. But I do not think these factors can entirely account for the results. After all, children could have chosen to write about other kinds of ritual. On the contrary, the overwhelming consideration given to funerals only serves to confirm the general picture in which a former balance between rites of the east and of the west has been lost. Rites of the east have borne the brunt of Christian disapproval, as well as suffering a loss of plausibility in the face of other aspects of social change (Waterson 2009: 350-1), while mortuary rituals have retained their place of honour as quintessential social events, and have even become more grandiose. At the same time, however, some children expressed the view that some aspects of Toraja ceremonies should be changed. These comments show a certain degree of ambivalence: 38.7 per cent stated that ceremonial culture must be preserved, while 25.2 per cent spoke of changing it. But these conflicting thoughts were sometimes combined; 24 (8.5 per cent) who were in favour of moderating the expenditure incurred at funerals also said that their culture must be preserved.

A total of 67 , or 23.8 per cent, of the children also chose to write their opinions about the burden of debt. High-schoolers in particular were likely to comment on the parental conflict between meeting ceremonial obligations and paying for their children's education; they are the ones most keenly aware of the obstacles in the way of their completing their schooling and, still more, pursuing higher education, which has become 
ever more expensive in the post-Suharto era. The following example from a middle-schooler provides a vivid visual image of the dilemma, clearly based on personal experience:

Ceremonies in Tana Toraja need to be preserved so that what is special about our culture won't be lost, but parents with children who are still in school ought to put their needs first. For instance, if we ask our mother for money to buy school books she won't give it, but suddenly she gets news that there is a funeral that must be attended the next day. Well, the next morning the pig will be there in front of the house, ready to take to the funeral. Actually, she said there is no money to buy books, but she's quite well able to buy a pig, so here we can see that parents may be more concerned about going to funerals than about fulfilling the needs of their children. (Girl, aged 14)

Others echoed this girl's concerns, or pointed out that traditional rituals disrupt the rationalised calendar of the modern working week:

What is most surprising is that parents say they haven't any money, but if a ritual comes around they are able to buy buffaloes and pigs and everything that is used in the ceremony. Maybe for this reason many Toraja children are unable to continue their education and don't finish high school or middle school. Their parents force them to migrate [merantau] to increase the family's income. (Girl, aged 16)

At funerals the family members compete with each other to sacrifice pigs and buffaloes just to win praise or to pay their debts. Logically isn't this ruinous [sangat merugikan]? To tire ourselves out looking for money only to use it all up in a single day buying buffaloes worth hundreds of millions of rupiah? Yet no thought is given to the children who are still getting an education? But in this matter Toraja are still Toraja, their character is such that you could say they don't want to be outdone by others [tidak man kalab]. (Girl, aged 17)

Ceremonies that are held on week days (not in school holidays) interfere with getting an education, because they usually go on for a week or more. (Girl, aged 16)

Apart from their own interests, some children expressed concern about the burden caused to the poor, who may feel obliged to try to keep face, even if they cannot afford it. One girl even went so far as to suggest that people may be driven out of their minds with worry on this score: 
I have noticed that many people are mad/not in their right minds [gila/ tidak waras] and it has occurred to me that they have been driven mad through worrying about all the debts they owe at ceremonies all over the place. (Girl, aged 16)

It is all very well for the rich to hold extravagant ceremonies, but those who force themselves to join in even when they can't afford it end up selling their house after the ceremony is over and living miserably, because they are burdened with debts all over the place. So it would be better if funerals were only held by those who are better off. Those who can't afford it would be better off not holding them because it will cause them anxiety later. (Boy, aged 17)

In my view ceremonies in Toraja cause families to go into debt. However we can't just say we haven't got anything to contribute, the point is you have to have something. If the family isn't well off they still have to try and hold a funeral ceremony because that is our adat that has been passed down to us over the generations. (Girl, aged 17)

I think Toraja ceremonies, especially funerals, are a real torment [sangat menyiksa] for the poor, because they are sometimes forced to borrow money in order to meet funeral expenses. (Boy, aged 17)

\section{Conclusion: The ceremonial economy and the enactment of empathy}

Children's statements about rituals, and funerals in particular, reveal just how much they have observed and tacitly absorbed about an ethos that compels the sharing of emotions, work and resources among kin. The moral imperative to know one's kin, and to support them in their ritual endeavours, finds its most vivid expression in the organisation of mortuary ritual, and it is sufficiently strong for some children already to see themselves migrating in search of work as adults in order to contribute to their own family's ceremonial expenses. Why, one might wonder, is there so little here about shared happiness? A few children, admittedly, did mention the sharing of joy as a counterpart to sorrow, but hardly any of them chose to write about the thanksgiving rituals traditionally associated with the east, or even about newer rituals, such as Christian weddings. Partly, I believe, this is due to the relative decline in salience, already mentioned, of the eastern half of the ritual corpus and the fact that, in practice, children will have attended funerals far more frequently than any other type of ritual. 
But partly this is doubtless also due to the stronger moral compulsion that exists to be present at, and contribute to, funeral rites. These are the events that activate the reciprocal duties of exchange between affines, who, as guests, must present their hosts with sacrificial livestock. I have argued elsewhere that these activities do not merely reflect, but rather are generative of, kinship relations (Waterson 2009). Family honour (longko') is at stake-hence the statements regarding the impossibility of opting out of contributing. But it is for this reason that adults sometimes claim special powers for the Toraja kinship system, in binding people to their culture and keeping it vigorous. Some people express the opinion that it is precisely the bilateral character of the Toraja kinship system, embedding every individual in a network of links to houses of origin, and obliging spouses to work together to meet ritual obligations to both their families, that constitutes that strength. Others comment that the ceremonial system forces Toraja people to be industrious to meet their obligations. Children's experiences of the communal efforts put into organising funerals have clearly given them insights into not only family cooperation, but also the competitive nature of sacrificing and the emotional strains that can result from being caught up in this high-stakes game. They sometimes feel the impact of this directly when their own parents are forced to make choices between ritual and educational expenditure.

In various responses, the elevation of kinship morality to the level of the community and, further, to Toraja cultural identity in general, can be seen. Children learn in school to be Indonesian citizens, and one entailment of this process is a heightened sense of local distinctiveness in relation to the many other ethnic groups making up the nation. Events in Indonesian politics since 1998 may also have made some impression; there were many Toraja migrants living both in Maluku and in Central Sulawesi-two areas worst hit by outbreaks of ethnic violence between Muslims and Christians in 1999-2000 — who had to flee their homes and who returned as refugees to the Toraja highlands at that time. Children may have relatives among this group of returnees or may have heard stories from their parents about that time. As inhabitants of the only Christian regency in the otherwise Muslim province of South Sulawesi, Toraja have also felt a heightened anxiety about the possible dangers of Islamic extremism since 11 September 2001 and the Bali bombings of 12 October 2002, as well as more recent attacks against churches in Java. A sense of connection to the wider world is enhanced by the increasing numbers of Toraja working overseas, as well as by tourist arrivals in the highlands. Tourism has suffered badly since 1999, but it still contributes 
to the local economy and Toraja people have long grown accustomed to foreign sightseers showing up at funerals. Children's repeated emphasis on the 'uniqueness' of their culture must be understood within this national and international context.

Turning to comparative Austronesian ethnography, the Polynesian examples discussed earlier suggest some interesting parallels. Toraja are not alone in claiming for themselves special moral virtues of empathy, as expressed through ritual. Nor are they unique in thus emphasising an image of empathy as a communal commitment, even if previous studies, such as those of Hollan, have largely focused on the dyadic dimensions of empathic involvement with others. Mageo's study of Samoa examines both intersubjective and group-focused styles of empathy, while proposing that the latter is the form that has primary cultural salience for Samoans. She suggests that a Samoan penchant for teasing contrasts with Hollan's account of a Toraja etiquette of politeness, which is designed to avoid shaming others and thus requiring that empathy be enacted all the time (Mageo 2011: 87-8). Hollan (2011: 204) notes that, among the Toraja, as among the Balinese, a contrasting cultural theme is that others, if offended, may seek revenge through black magic. Indeed, the inverse of the image of compassion and cooperation in the staging of rituals is the competitive streak that may putatively lead others to do magic to upset the smooth performance of a rite, by causing rain, upset stomachs among the guests or loss of voice in a competing ma'badong group (Rappoport 1999). Mageo also cautions that idealised cultural forms are not simply upheld without resistance; a variety of Samoan turns of phrase also describe the exhaustion brought on by hosting visitors and the efforts that may be made to avoid them. We must be alive to these nuances, and will do well to avoid overstressing a simplistic binary opposition between individualist and collectivist orientations in different cultures, since these are not mutually exclusive options, and individuals within any cultural grouping will also differ in their emotional style. Yet, Mageo makes an important point that Samoans set little store by mere statements of empathy; its collective expression must be demonstrated through actions. She goes further to suggest that 'enacted empathy is the constitutive practice of what Mauss calls "gift economies"' (Mageo 2011: 76). I find this idea worthy of further comparative exploration, since I have argued elsewhere (Waterson 2009: 395-430) that economies-particularly, but by no means only, those involving ceremonial exchange-cannot be understood without also delineating their emotional aspects. Toraja children's understandings of ritual, as revealed here, likewise point to a conviction 
that core cultural values must be expressed in action. Children learn these shared values most vividly through their direct participation in ritual events. My findings show them actively making sense of their experience and forming diverse opinions about it. Whatever their misgivings about the ceremonial burdens that their culture will shortly impose on them as adults, they are already poised to take up the challenge.

\section{References}

Adams, Kathleen. 1993. 'The discourse of souls in Tana Toraja (Indonesia): Indigenous notions and Christian conceptions'. Ethnology 32(1): 55-68. doi.org/10.2307/3773545.

Adams, Kathleen. 1997. 'Ethnic tourism and the renegotiation of tradition in Tana Toraja (Sulawesi, Indonesia)'. Ethnology 36(4): 309-20. doi.org/10.2307/3774040.

Akin, David and Joel Robbins (eds). 1999. Money and Modernity: State and local currencies in Melanesia. Pittsburgh: University of Pittsburgh Press.

Alderson, Priscilla and Virginia Morrow. 2004. Ethics, Social Research and Consulting with Children and Young People. Essex, UK: Barnado's.

Barbalet, J. M. 1994. 'Ritual emotion and body work: A note on the uses of Durkheim'. In David Franks, William Wentworth and John Ryan (eds) Social Perspectives on Emotion. Volume 2, pp. 111-23. Greenwich, CT: JAI Press.

Baron-Cohen, Simon. 2011. Zero Degrees of Empathy: A new theory of human cruelty. London: Allen Lane.

Bastiaansen, J., M. Thioux and C. Keysers. 2009. 'Evidence for mirror systems in emotions'. Philosophical Transactions: Biological Sciences 364(1528): 2391-404. doi.org/10.1098/rstb.2009.0058.

Bateson, Gregory. 1958. Naven. 2nd edn. London: Wildwood House.

Beazley, Harriott, Sharon Bessell, Judith Ennew and Roxana Waterson. 2009. 'The right to be properly researched: Research with children in a messy, real world'. Children's Geographies 7(4): 365-78. doi.org/ $10.1080 / 14733280903234428$. 
Boyden, Jo and Judith Ennew (eds). 1997. Children in Focus: A manual for participatory research with children. Stockholm: Radda Barnen.

Christensen, Pia and Alison James (eds). 2008. Research with Children: Perspectives and practices. 2nd edn. London: Falmer Press.

Decety, Jean and William Ickes. 2009. The Social Neuroscience of Empathy. Cambridge, MA: MIT Press. doi.org/10.7551/mitpress/ 9780262012973.001.0001.

Decety, Jean and Peter Jackson. 2004. 'The functional architecture of human empathy'. Behavioral and Cognitive Neuroscieince Review 3: 71-100. doi.org/10.1177/1534582304267187.

de Jong, Edwin. 2008. Living with the Dead: The economics of culture in the Torajan highlands, Indonesia. Nijmegen, Netherlands: Radboud University Nijmegen.

de Jong, Edwin. 2013. Making a Living between Crises and Ceremonies in Tana Toraja: The practice of everyday life of a South Sulawesi highland community in Indonesia. Leiden: Brill.

Donzelli, Aurora. 2003. "'Sang Buku Duang Buku Kada” (one or two words): Communicative practices and linguistic ideologies in the Toraja highlands of eastern Indonesia'. PhD thesis. University of Milano-Bicocca, Milan.

Durkheim, Emile. 1982 [1915]. The Elementary Forms of the Religious Life. 2nd edn. London: Allen \& Unwin.

Eisenberg, Nancy and Janet Strayer (eds). 1987. Empathy and its Development. Cambridge: Cambridge University Press.

Elias, Norbert. 1994 [1939]. The Civilizing Process. Oxford: Blackwell.

Ennew, Judith. 2009. The Right to be Properly Researched: How to do rights-based, scientific research with children. Bangkok: Black on White Publications.

Fortes, Meyer. 1970 [1938]. 'Social and psychological aspects of education in Taleland'. In Meyer Fortes, Time and Social Structure and Other Essays, pp. 201-59. London: Athlone Press. 
Frith, Chris. 2007. 'The social brain?' Philosophical Transactions of the Royal Society B 362: 671-8. doi.org/10.1098/rstb.2006.2003.

Gallagher, Shaun. 2012. 'Empathy, simulation, and narrative'. Science in Context 25(3): 355-81. doi.org/10.1017/S0269889712000117.

Gallese, Vittorio. 2001. 'The "shared manifold" hypothesis: From mirror neurons to empathy'. Journal of Consciousness Studies 8: 33-50.

Gallese, Vittorio. 2007. 'Embodied simulation: From mirror neuron systems to interpersonal relations'. In Greg Bock and Jamie Goode (eds) Empathy and Fairness: Novartis Foundation Symposium 278, pp. 3-19. Chichester, UK: John Wiley.

Geertz, Clifford. 1984 [1976]. 'From the native's point of view: On the nature of anthropological understanding'. In Richard A. Schweder and Robert A. LeVine (eds) Culture Theory: Essays on Mind, Self and Emotion, pp. 123-36. Cambridge: Cambridge University Press.

Geertz, Hildred. 1974 [1959]. 'The vocabulary of emotion: A study of Javanese socialization processes'. In Robert A. LeVine (ed.) Culture and Personality: Contemporary Readings. Chicago: Aldine.

Goldman, Laurence. 1998. Child's Play: Myth, mimesis and make-believe. Oxford: Berg.

Gregory, C. 1980. 'Gifts to men and gifts to god: Gift exchange and capital accumulation in contemporary Papua'. Man (NS) 15(4): 626-52. doi.org/10.2307/2801537.

Heider, Karl. 1991. Landscapes of Emotion: Mapping three cultures of emotion in Indonesia. Cambridge: Cambridge University Press. doi.org/10.1017/CBO9780511527715.

Hoffman, Martin. 2000. Empathy and Moral Development: Implications for caring and justice. Cambridge: Cambridge University Press. doi.org/10.1017/CBO9780511805851.

Hollan, Douglas. 1988. 'Staying "cool" in Toraja: Informal strategies for the management of anger and hostility in a nonviolent society'. Ethos 16(1): 52-72. doi.org/10.1525/eth.1988.16.1.02a00030. 
Hollan, Douglas. 1990. 'Indignant suicide in the Pacific: An example from the Toraja highlands of Indonesia'. Culture, Medicine and Psychiatry 14: 365-79. doi.org/10.1007/BF00117561.

Hollan, Douglas. 1992a. 'Cross-cultural differences in the self'. Journal of Anthropological Research 48(4): 283-300. doi.org/10.1086/jar.48.4. 3630440 .

Hollan, Douglas. 1992b. 'Emotion work and the value of emotional equanimity among the Toraja'. Ethnology 31(1): 45-56. doi.org/ $10.2307 / 3773441$.

Hollan, Douglas. 2008. 'Being there: On the imaginative aspects of understanding others and being understood'. Ethos 36(4): 475-89. doi.org/10.1111/j.1548-1352.2008.00028.x.

Hollan, Douglas. 2011. "Vicissitudes of "empathy" in a rural Toraja village'. In Douglas W. Hollan and C. Jason Throop (eds) The Anthropology of Empathy: Experiencing the lives of others in Pacific societies, pp. 194-214. New York: Berghahn Books.

Hollan, Douglas and C. Jason Throop. 2008. 'Whatever happened to empathy? Introduction'. Ethos 36(4): 385-401. doi.org/10.1111/ j.1548-1352.2008.00023.x.

Hollan, Douglas W. and C. Jason Throop (eds). 2011. The Anthropology of Empathy: Experiencing the lives of others in Pacific societies. New York: Berghahn Books.

Hollan, Douglas and Jane Wellenkamp. 1994. Contentment and Suffering: Culture and experience in Toraja. New York: Columbia University Press.

Hollan, Douglas and Jane Wellenkamp. 1996. The Thread of Life: Toraja reflections on the life cycle. Honolulu: University of Hawai'i Press.

Hume, David. 1739-40. A Treatise of Human Nature: Being an attempt to introduce the experimental method of reasoning into moral subjects. London: John Noon.

Hume, David. 1751. An Enquiry Concerning the Principles of Morals. London: A. Millar.

Iacoboni, Marco. 2008. Mirroring People: The new science of how we connect with others. New York: Farrar, Straus \& Giroux. 
Iacoboni, Marco, Istvan Molnar-Szakacs, Vittorio Gallese, Giovanni Buccino, John C. Mazziotta and Giacomo Rizzolatti. 2005. 'Grasping the intentions of others with one's own mirror neuron system'. PLoS Biology 3(3): 529-35. doi.org/10.1371/journal.pbio.0030079.

Ingold, Tim. 1985. 'Who studies humanity? The scope of anthropology'. Anthropology Today 1(6): 15-16. doi.org/10.2307/3033249.

Jakoby, Nina. 2012. 'Grief as a social emotion: Theoretical perspectives'. Death Studies 36(8): 679-711. doi.org/10.1080/07481187.2011. 584013.

Koubi, Jeanine. 1982. Rambu Solo, 'La Fumée Descend': Le Culte des Morts chez les Toradja du Sud [Rambu Solo' 'The Smoke Descends': The cult of the dead among the southern Toraja]. [In French.] Paris: CNRS.

Latour, Bruno. 1993. We Have Never Been Modern. New York: Harvester Wheatsheaf.

Levy, Robert. 1973. Tahitians: Mind and society in the Society Islands. Chicago: University of Chicago Press.

Lipps, Theodor. 1903-06. Ästhetik: Psychologie des Schönen und der Kunst [Aesthetics: The Psychology of Beauty and Art]. 2 Vols. Hamburg and Leipzig: Leopold Voss.

Lohmann, Roger. 2011. 'Empathic perception and imagination among the Asabano: Lessons for anthropology'. In Douglas W. Hollan and C. Jason Throop (eds) The Anthropology of Empathy: Experiencing the lives of others in Pacific societies, pp. 94-116. New York: Berghahn Books.

Lutz, Catherine. 1988. Unnatural Emotions: Everyday sentiments on a Micronesian atoll and their challenge to Western theory. Chicago: University of Chicago Press.

Lutz, Catherine and Geoffrey White. 1986. 'The anthropology of emotions'. Annual Review of Anthropology 15: 405-36. doi.org/ 10.1146/annurev.an.15.100186.002201.

Mageo, Jeanette. 2011. 'Empathy and "as-if" attachment in Samoa'. In Douglas W. Hollan and C. Jason Throop (eds) The Anthropology of Empathy: Experiencing the lives of others in Pacific societies, pp. 68-93. New York: Berghahn Books. 
Meloni, Maurizio. 2014. 'Biology without biologism: Social theory in a postgenomic age'. Sociology 48(4): 731-46. doi.org/ $10.1177 / 0038038513501944$.

Myers, Fred. 1979. 'Emotions and the self: A theory of personhood and political order among Pintupi Aborigines'. Ethos 7(4): 343-70. doi.org/10.1525/eth.1979.7.4.02a00030.

Nooy-Palm, Hetty. 1986. The Sa'dan Toraja: A study of their social life and religion. Volume II: Rituals of the east and west. Dordrecht: Foris.

Parker, Lyn. 1997. 'Engendering school children in Bali'. Journal of the Royal Anthropological Institute 3(3): 497-516. doi.org/10.2307/3034764.

Parker, Lyn. 2002. 'The subjectification of citizenship: Student interpretations of school teachings in Bali'. Asian Studies Review 26(1): 3-37. doi.org/10.1080/10357820208713329.

Preston, Stephanie and Frans de Waal. 2002. 'Empathy: Its ultimate and proximate bases'. Behavioral and Brain Sciences 25: 1-72.

Rappoport, Dana. 1999. 'Chanter sans être Ensemble. Des Musiques Juxtaposées pour un Public Invisible [Singing without being together. Juxtaposed music for an invisible audience]'. [In French.] L'Homme 39(152): 143-62. doi.org/10.3406/hom.1999.453666.

Rappoport, Dana. 2009. Songs from the Thrice-Blooded Land: Ritual music of the Toraja (Sulawesi, Indonesia). Volume One: Ethnographic narrative. Volume Two: Florilegium Toraja-A selection of Toraja songs. Volume Three [DVD]: Multimedia argument/multimedia musical anthology. Paris: Editions Epistèmes/Editions de la Maison des Sciences de L'Homme.

Read, K. E. 1955. 'Morality and the concept of the person among the Gahuku-Gama'. Oceania 25(4): 233-82. doi.org/10.1002/j.18344461.1955.tb00651.x.

Rizzolatti, Giacomo and Laila Craighero. 2004. 'The mirror neuron system'. Annual Review of Neuroscience 27: 169-92. doi.org/10.1146/ annurev.neuro.27.070203.144230.

Robins, Joel and Alan Rumsey. 2008. 'Introduction: Cultural and linguistic anthropology and the opacity of other minds'. Anthropological Quarterly 81(2): 407-20. doi.org/10.1353/anq.0.0005. 
Rollason, Will. 2012. 'Review of D. Hollan \& C. J. Throop (eds). The Anthropology of Empathy: Experiencing the Lives of Others in Pacific Societies'. Journal of the Royal Anthropological Institute (NS)18(3): 706-7. doi.org/10.1111/j.1467-9655.2012.01787_15.x.

Rosaldo, Michelle. 1980. Knowledge and Passion: Ilongot notions of self and social life. Cambridge: Cambridge University Press. doi.org/10.1017/ CBO9780511621833.

Rosaldo, Renato. 1984. 'Grief and a headhunter's rage: On the cultural force of emotions'. In Edward M. Bruner (ed.) Text, Play, and Story: The construction and reconstruction of self and society. Stanford, CA: Stanford University Press.

Smith, Adam. 1759. The Theory of Moral Sentiments. London: A. Millar.

Stamenov, Maxim and Vittorio Gallese. 2002. Mirror Neurons and the Evolution of Brain and Language. Amsterdam: John Benjamins. doi.org/10.1075/aicr.42.

Stearns, Peter and Deborah Stearns. 1994. 'Historical issues in emotions research: Causation and timing'. In David Franks, William Wentworth and John Ryan (eds) Social Perspectives on Emotion. Volume 2, pp. 239-66. Greenwich, CT: JAI Press.

Stewart, Pamela J. and Andrew Strathern (eds). 2009. Religious and Ritual Change: Cosmologies and histories. Durham, NC: Carolina Academic Press.

Stueber, Karsten. 2006. Rediscovering Empathy: Agency, folk psychology, and the human sciences. Cambridge, MA: MIT Press.

Throop, C. Jason. 2011. 'Suffering, empathy, and ethical modalities of being in Yap (Waqab), Federated States of Micronesia'. In Douglas W. Hollan and C. Jason Throop (eds) The Anthropology of Empathy: Experiencing the lives of others in Pacific societies, pp. 118-49. New York: Berghahn Books.

Toren, Christina. 1990. Making Sense of Hierarchy: Cognition as social process in Fiji. Basingstoke, UK: Palgrave Macmillan.

Toren, Christina. 1993. 'Making history: The significance of childhood cognition for a comparative anthropology of mind'. Man (NS)28(3): 461-78. doi.org/10.2307/2804235. 
Toren, Christina. 1999. 'Compassion for one another: Constituting kinship as intentionality in Fiji'. Journal of the Royal Anthropological Institute 5(2): 265-80. doi.org/10.2307/2660697.

Toren, Christina. 2006. 'The effectiveness of ritual'. In Fenella Cannell (ed.) The Anthropology of Christianity, pp. 185-210. Durham, NC: Duke University Press. doi.org/10.1215/9780822388159-007.

Vischer, Robert. 1994 [1873]. 'On the optical sense of form: A contribution to aesthetics'. In Harry Francis Mallgrave and Eleftherios Ikonomon (eds) Empathy, Form and Space: Problems in German aesthetics, 18731893. Santa Monica, CA: Getty Centre for the History of Art and the Humanities.

Volkman, Toby. 1979. 'The riches of the undertaker'. Indonesia 28: 1-16. doi.org/10.2307/3350893.

Volkman, Toby. 1985. Feasts of Honour: Ritual and change in the Toraja highlands. Chicago: University of Illinois Press.

Volkman, Toby. 1987. 'Mortuary tourism in Tana Toraja'. In Rita Smith Kipp and Susan Rodgers (eds) Indonesian Religions in Transition, pp. 161-7. Tucson: University of Arizona Press.

Wassmann, Jürg, Birgit Träuble and Joachim Funke (eds). 2013. Theory of Mind in the Pacific: Reasoning across cultures. Heidelberg: Universitätsverlag Winter.

Waterson, Roxana. 1984. 'Rites of east and west: Ritual, gender and status in Tana Toraja'. In Roxana Waterson Ritual and belief among the Sa'dan Toraja. Occasional Paper No. 2, pp. 3-33. Canterbury, UK: University of Kent Centre of South-East Asian Studies.

Waterson, Roxana. 1993. 'Taking the place of sorrow: The dynamics of mortuary rites among the Sa'dan Toraja'. Southeast Asian Journal of Social Science 21(2): 73-96. doi.org/10.1163/030382493X00125.

Waterson, Roxana. 1995. 'Entertaining a dangerous guest: Sacrifice and play in the Ma'pakorong ritual of the Sa'dan Toraja'. Oceania 66(2): 81-102. doi.org/10.1002/j.1834-4461.1995.tb02538.x.

Waterson, Roxana. 2009. Paths and Rivers: Sa'dan Toraja society in transformation. Leiden: KITLV Press. doi.org/10.1163/ 9789004253858 . 
Waterson, Roxana. 2015. 'Children's perspectives on ritual and its responsibilities among the Sa'dan Toraja of Sulawesi (Indonesia)'. Journal of Ritual Studies 29(1): 49-69.

Wellenkamp, Jane. 1984. 'A psychocultural study of loss and death among the Toraja'. PhD thesis. University of California, San Diego.

Wellenkamp, Jane. 1988. 'Notions of grief and catharsis among the Toraja'. American Ethnologist 15: 486-500. doi.org/10.1525/ae.1988. 15.3.02a00050.

Wellenkamp, Jane. 1991. 'Fallen leaves: Death and grieving in Toraja'. In David R. Counts and Dorothy A. Counts (eds) Coping with the Final Tragedy: Cultural variation in dying and grieving, pp. 113-34. Amityville, NY: Baywood.

Wellenkamp, Jane. 1992. 'Variation in the social and cultural organization of emotions: The meaning of crying and the importance of compassion in Toraja, Indonesia'. In D. D. Franks and V. Gecas (eds) Social Perspectives on Emotion. Volume 1. Greenwich, CT: JAI.

White, Geoffrey. 1993. 'Emotions inside out: The anthropology of affect'. In Michael Lewis and Jeannette M. Haviland (eds) Handbook of Emotions, pp. 29-40. New York: Guilford Press.

White, Geoffrey and John Kirkpatrick (eds). 1985. Person, Self and Experience: Exploring Pacific ethnopsychologies. Berkeley, CA: University of California Press.

Yamashita, Shinji. 1997. 'Manipulating ethnic tradition: The funeral ceremony, tourism, and television among the Toraja of Sulawesi, Indonesia'. In Shinji Yamashita, Kadir H. Din and J. S. Eades (eds) Tourism and Cultural Development in Asia and Oceania, pp. 83-103. Bangi, Malaysia: University of Malaysia Press.

Young, Allan. 2012. 'The social brain and the myth of empathy'. Science in Context 25(3): 401-24. doi.org/10.1017/S0269889712000129. 


\section{Appendix 4.1: Numerical figures}

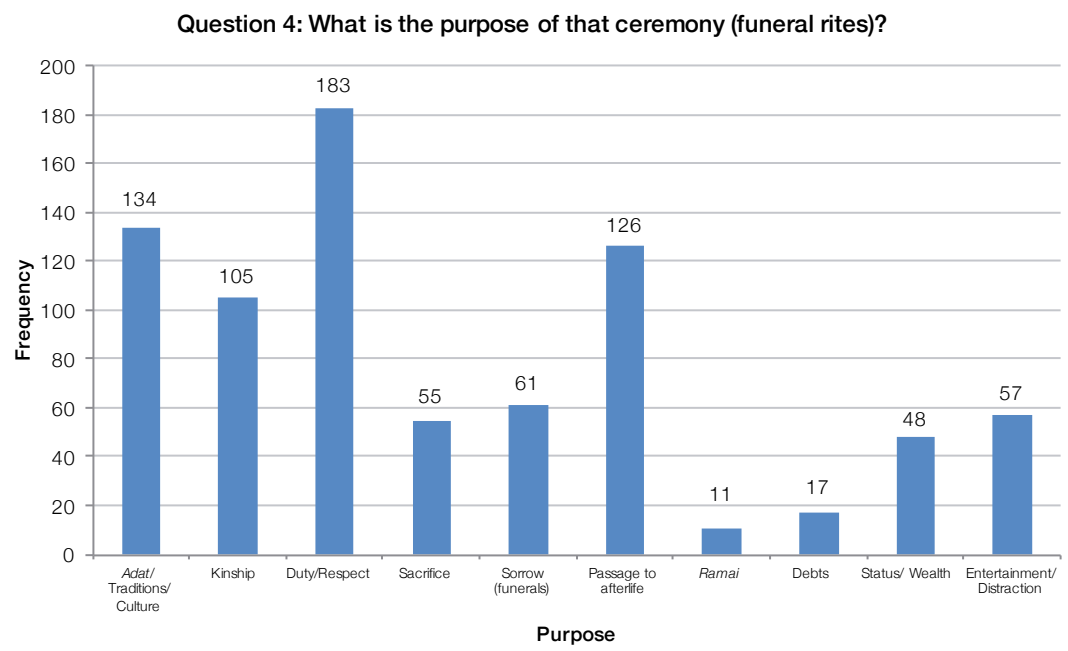

Figure A4.1 Answers to Question 4

Notes: $n=436$. Most children gave multiple answers, therefore frequencies exceed the total number of participants; 15 gave no answer.

Source: Author's data.

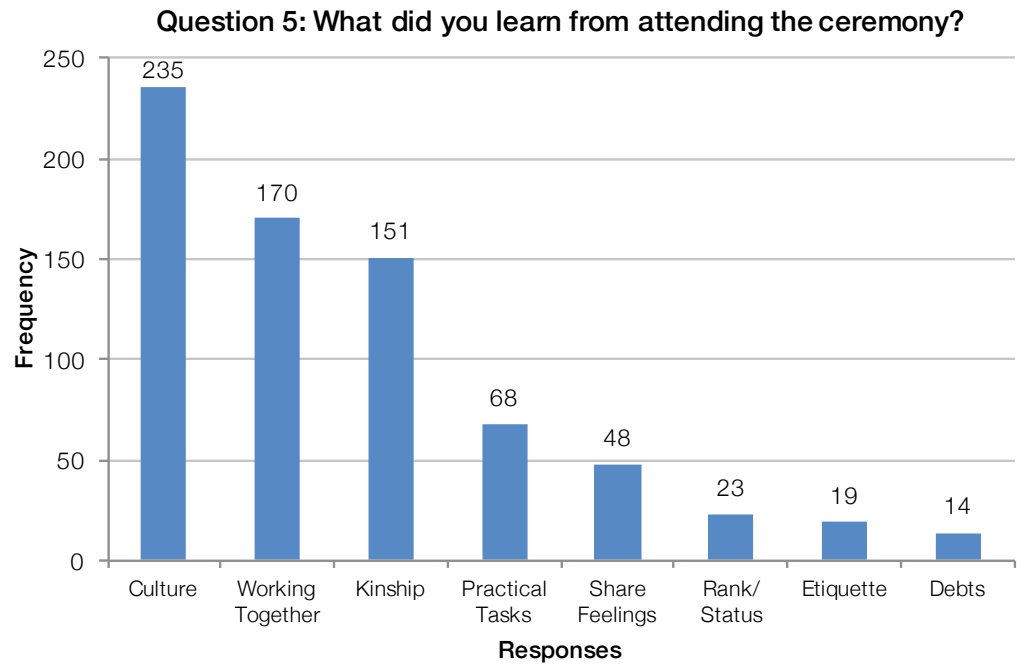

Figure A4.2 Answers to Question 5

Notes: $n=441$; most children gave multiple answers, therefore frequencies exceed total number of participants; 10 gave no answer.

Source: Author's data. 
Question 6: What will you do when you are grown up if someone in your family is having a ceremony?

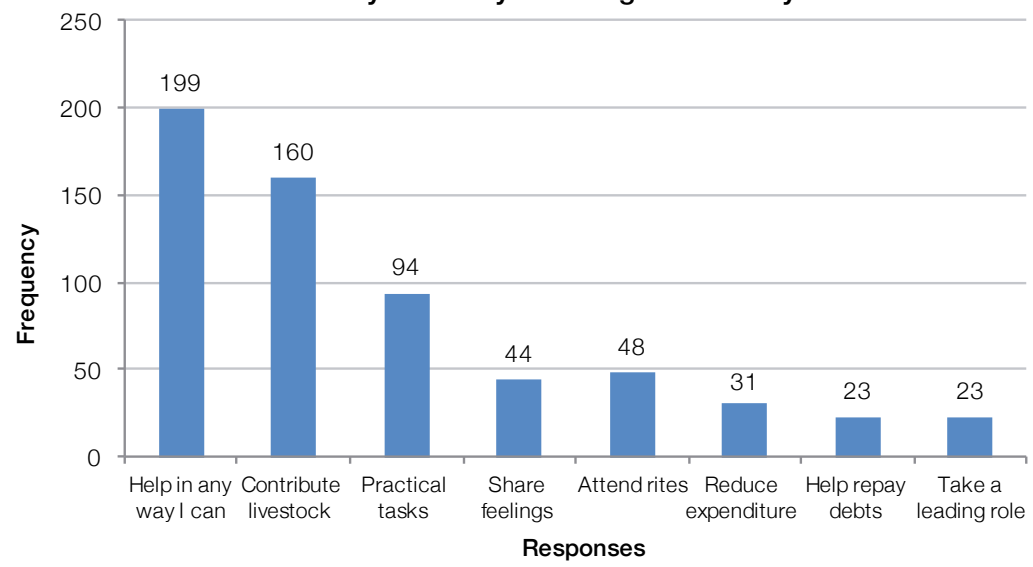

Figure A4.3 Answers to Question 6

Notes: $n=424$; most children gave multiple answers, therefore frequencies exceed total number of participants; 27 gave no answer.

Source: Author's data.

\section{Question 7: Is there anything else you would like to tell me} about ceremonies?

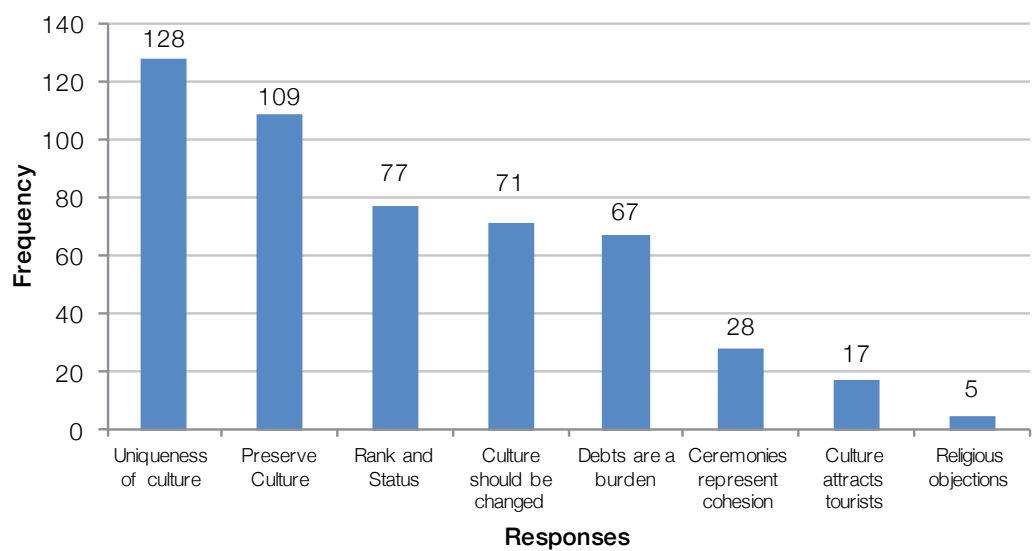

Figure A4.4 Answers to Question 7

Notes: $\mathrm{n}=282$; most children gave multiple answers, therefore frequencies do not match the number of participants; 169 gave no answer.

Source: Author's data. 
This text is taken from Expressions of Austronesian Thought and Emotions, edited by James J. Fox, published 2018 by ANU Press, The Australian National University, Canberra, Australia.

doi.org/10.22459/EATE.04.2018.04 